\title{
Editorial
}

\section{A legacy to continue}

\section{Colin Rhinesmith}

\author{
Editor in Chief, The Journal of Community \\ Informatics \\ crhinesmith@simmons.edu
}

This editorial marks the second transition in Editorship of the Journal of Community Informatics since Michael Gurstein founded the Journal in 2004 as part of a world-wide community of researchers and practitioners of the emerging field of community informatics. Eduardo Villanueva-Mansilla took over as Editor in 2016 and successfully stewarded the Journal through challenging times, including Michael's passing in 2017. On behalf of our global community of researchers and practitioners, I want to say thank you to Eduardo for his leadership and to the editorial team that played such a significant role in continuing Michael's legacy with the Journal.

As Eduardo did when he first assumed his role of Editor-in-Chief, I too will use this space to briefly introduce myself. I am an Associate Professor and Director of the Community Informatics Lab in the Simmons University School of Library and Information Science located in Boston, Massachusetts and a former Faculty Associate with the Berkman Klein Center for Internet \& Society at Harvard University. I have participated in this community as a researcher and practitioner at the intersection of community media and technology for over fifteen years.

Since learning about the Journal of Community Informatics shortly after its launch, I have centered my scholarly commitments on producing actionable research to describe how community-based organizations, such as community media centers and public libraries, promote digital inclusion and broadband adoption in their communities. I am fortunate and grateful to say that this research has since benefited practitioners, researchers, and policymakers working to address digital inequalities and promote digital equity in the United States and around the world.

While the Editorship will move to the United States, I promise to preserve and maintain the Journal's international core. I am excited and honored to announce our impressive new Editorial Board, and I will look to the Board's deep expertise and knowledge to help maintain the Journal's unique international approach.

This change in stewardship is also an opportunity to introduce some new ideas and approaches, both intellectual as well as operational, to continue the Journal's novelty and relevance today. Toward this goal, I want to share some changes and updates that have been made to the Journal. 
1. The Journal has moved back home to Canada. It is now hosted at the University of Waterloo Library. I am grateful to David Nemer who assisted me with this transition from its previous home at the University of Kentucky over the past several years, under Eduardo Villanueva-Mansilla's leadership. I am also grateful to Peter Johnson at the University of Waterloo Library who played a significant role in helping us to transition the Journal to its new home.

2. The Journal has three new Associate Editors as well as new Review Editor. I am excited to announce that Tom Denison of Monash University and Peter Johnson of the University of Waterloo have joined Eduardo Villanueva-Mansilla as Associate Editors. Vanessa Rhinesmith, Executive Director of the Center for Critical Internet Inquiry at the University of California Los Angeles, will assume the role of Review Editor.

3. The Editorial Board is worth mentioning once again here. I am thankful to them for agreeing to help keep this journal vibrant, to maintain its high quality of peer-review, and to continue to build the Journal's vision into the future. The members, new and returning, can be found on our website. ${ }^{1}$

This change in stewardship at the Journal comes during a time of global crisis in 2020. As of the time this Editorial was written, the World Health Organization ${ }^{2}$ confirmed $75,110,651$ cases of COVID-19 in 222 countries and 1,680,395 deaths, as a result. In many countries, hospitals are overwhelmed in ways never seen before and many other workers around the world are risking their lives so others can stay at home. "Social distancing," or the term I prefer to use, "physical distancing," is the phrase being promoted by our health care experts and political leaders. At the same time, the impacts of this health care crisis have created enormous strains on our global economy as well as on our global Internet, particularly for those who have access and can afford its high costs, as seen in the United States.

This latest health crisis has only heightened other global challenges, including impacts on our environment and our communities living in poverty. I strongly hesitate to say that community informatics, in general, and this Journal, more concretely, have the answers to these tremendous global challenges facing us today. However, I will say that community informatics and this Journal have helped to remind us over the years that our sense of community and our need as human beings to stay connected remains incredibly important regardless of technology. Therefore, I remain hopeful that this Journal and its thoughtful community of researchers and practitioners will continue to show the ongoing relevance of community informatics through our current crises and long into the future. This is our call today.

\footnotetext{
https://openjournals.uwaterloo.ca/index.php/JoCI/about/editorialTeam

${ }^{2}$ https://www.who.int/emergencies/diseases/novel-coronavirus-2019
} 